\title{
Fixation of distal femoral fractures: Restoration of the knee motion
}

\author{
Elsayed Ibraheem Elsayed Massoud, M.D.
}

Department of Orthopaedic, Sohag Teaching Hospital, General Organization for Teaching Hospitals and Institutes, Sohag, Egypt

\begin{abstract}
BACKGROUND: Most of healed lower femoral fractures resulted in various degree of loss of the knee motion. Flexion deficit is a serious problem for the Eastern persons that are where squatting and sitting on the ground are necessary for daily activities. The aims of this study were to compare outcomes of using condylar buttress plate and dynamic condylar screw (DCS) in treatment of distal femoral fractures. Secondly, we present our clinical experience for optimizing the technical application of the studied implants.

METHODS: Two groups (plate and DCS) of 57 patients were treated for 59 lower femoral fractures with condylar buttress plate or DCS and followed prospectively for 24 months.

RESULTS: Plate group reported adequate reduction in $67 \%$ and varus angulation in $13.3 \%$ of the fractures. DCS group reported adequate reduction in $72.4 \%$ and posterior angulations in $17 \%$ of the fractures. Other reasons for inadequacy of reduction were reported in both groups. Full knee motion range was achieved in 50\% of plate group and in 55\% of DCS group. $75 \%$ and $90 \%$ satisfactory functional outcomes were reported in the plate and DCS groups respectively.
\end{abstract}

CONCLUSION: Both implants nearly achieved equal results concerning restoration of knee motion range. The condylar buttress plate and DCS are liable for technical optimization.

Key words: Condylar buttress plate; dynamic condylar screw; fracture; knee motion; lower femur.

\section{INTRODUCTION}

Most healed lower femoral fractures result in various degree of loss in knee motion. Fractures treated conservatively complicate with extension lag, flexion deficit or locked knee. Deformity and loss of knee motion have led to widespread attempts at internal fixation. ${ }^{[1]}$ However, surgical treatment has preserved knee extension but failed in restoration of the knee flexion. Fixation using retrograde nails obligates healing with posterior angulation particularly if the distal interlocking screws are fixed while the knee is extended. Posterior attachment of the gastrocnemius muscle encouraged healing with posterior angulation. ${ }^{[2,3]}$ On the other hand, dynamic condylar screw (DCS) and condylar buttress plate give liberty for surgeon to adjust flexion and extension of the distal fragment

\begin{tabular}{|c|c|}
\hline \multicolumn{2}{|c|}{ Address for correspondence: Elsayed Ibraheem Elsayed Massoud, M.D. } \\
\hline Tel: +2 $0934790632 \quad E$ & Isayedmassoud@hotmail.com \\
\hline Qucik Response Code & Ulus Travma Acil Cerrahi Derg \\
\hline 口itg & $\begin{array}{l}20|5 ; 2|(3): 197-203 \\
\text { doi: } 10.5505 / \text { tjtes.20I5.00490 }\end{array}$ \\
\hline a:tar & $\begin{array}{l}\text { Copyright } 2015 \\
\text { TJTES }\end{array}$ \\
\hline
\end{tabular}

at the main fracture line ${ }^{[4]}$ Flexion deficit is a serious problem for Eastern people who need to squat and sit on the ground for daily activities, which renders a search for a technique that restores knee motion range mandatory.

The aim of this study was to compare the outcomes of using condylar buttress plate and DCS in the treatment of distal femoral fractures. Our clinical experience for optimizing technical application of the studied implants was also presented.

\section{MATERIALS AND METHODS}

Fifty-seven patients, who agreed to participate in this prospective study between October 2006 and October 201I, were included and managed for 59 lower femoral fractures. Local Ethics Committee approved the study. The fracture patterns were determined radiographically according to AO classification. Preoperative details of the included patients are listed in Table I. The mean age of the patients at the time of operation was 48 years (range, 24-82 years). The patients were divided into two groups, consisting the plate group and DCS group. The plate group included twenty-eight patients with 30 fractures, of which two were type B3 that was not encountered lone in this study. Coronal fractures (type B3) were fixed using $6.5 \mathrm{~mm}$ cancellous screws. The DCS group 
included twenty-nine patients with 29 fractures.

A thigh tourniquet was used when the fracture did not extend too far proximally. Primary bone grafting was not done for any of our patients.

Postoperative management was individualized based on the quality of reduction obtained. Active and passive knee motions were started on the second postoperative day. Patients were allowed to walk using crutches and toe touch until absence of pain and a good callus had been observed on radiographs. Afterwards, progressive weight bearing was started. However, if the reduction was considered inadequate, partial weight bearing was allowed only when the callus bridged the fracture gap. Follow-up reviews were undertaken at every other week for 16 weeks, and then monthly. After the first year, patients were re-evaluated twice per year. The outcomes were assessed 24 months postoperatively.

\section{Radiological Assessment}

Reduction was categorized adequate if there was no angulation (extension/flexion, varus/valgus), displacement or rotation at the main fracture line. Angulation $>10^{\circ}$, displacement between the main proximal and distal segments $>2 \mathrm{~mm}$ or rotation was deemed inadequate. Displacements between the fragments within the articular block would be considered a technical failure of fixation. Angulations (varus/valgus and extension/flexion) were assessed by measuring the anatomic lateral distal femoral angle and anatomic posterior distal femoral angle, respectively. The anatomic lateral distal femoral angle describes the intersection between the anatomic axis and the horizontal line tangential to the subchondral surface of the femoral condyles, its normal mean value is $81^{\circ}$ (range: $79-83^{\circ}$ ). The anatomic posterior distal femoral angle describes the intersection between the anatomic axis and the sagittal distal femoral joint orientation line, its normal mean value is $83^{\circ}$ (range: $79-87^{\circ}$ ). ${ }^{[5,6]}$ Proper rotation of the distal segment was judged radiographically using one of the techniques described by Krettek et al. ${ }^{[7]}$ These techniques include: I) cortical thickness 2) cortical diameters and 3) profile of the lesser trochanter. Choosing any of these technique depends on fracture pattern, site and comminution at the fracture line.

Technical failures were defined as screw penetration of ar- ticular surface of the distal articular block, displacement $>2$ $\mathrm{mm}$ between the femoral condyles or condylar fragments (type B3 fracture), implant breakage or loosening, or nonunion. Penetration of the medial cortex was not considered a technical failure.

The fracture was defined healed if there were visible trabeculae across the fracture line. Time to union was calculated from the surgery date to the healing date. Non-union was defined as the absence of bridging bone at the fracture line by follow-up at 12 months, including progressive displacements.

\section{Clinical Assessment}

Knee joint motion was measured using a goniometer and compared to the healthy side. Leg length was assessed by measuring the distance between the anterior superior iliac spine and the tip of medial malleolus. Lengths of the lower extremities were compared. Functional outcome was classified according to Schatzker and Lambert criteria. ${ }^{\left[{ }^{8]}\right.}$ The results were then classified satisfactory (excellent and good) and unsatisfactory (fair and poor).

\section{Statistical Analysis}

The results were expressed as maximum and minimum values, mean and standard deviation (SD). $Z$ test was used for unpaired groups and nominal (categorical) data was used in the comparison between the plate group and the DCS group variables. Wilcoxon Rank Sum Test (Mann-Whitney $U$ test) for unpaired data was used in the comparison between the plate group and the DCS group. Significance was set at $p<0.05$. Microsoft Excel 2010 was used, and the web site was http://www.socscistatistics.com/tests/ztest/Default2.aspx

\section{RESULTS}

The baseline data of the patients included into the study are listed in Table I. Reduction was categorized in the plate group as adequate in 20 fractures (67\%) and inadequate in 10 fractures (33\%). In the DCS group, reduction was categorized as adequate in 21 fractures $(72.4 \%)$ and inadequate in 8 fractures (27.6\%) (Table 2). Difference between the two groups using $Z$ test, was statistically insignificant $(p=0.63122)$. Reasons for inadequate reduction in the plate group were varus angulation in 4 fractures (13.3\%), displacement between the main proxi-

Table I. Preoperative baseline data for two groups of patients with lower femoral fractures

\begin{tabular}{|c|c|c|c|c|c|c|c|c|c|c|c|c|c|c|c|}
\hline \multirow[t]{3}{*}{ Groups } & \multirow[t]{3}{*}{ Patients No. } & \multirow[t]{3}{*}{ Fractures No } & \multicolumn{2}{|c|}{ Side } & \multicolumn{2}{|c|}{ Sex } & \multicolumn{9}{|c|}{ Fracture types } \\
\hline & & & \multirow[t]{2}{*}{ Right } & \multirow[t]{2}{*}{ Left } & \multirow[t]{2}{*}{ Male } & \multirow[t]{2}{*}{ Female } & \multicolumn{3}{|c|}{ Type A } & \multicolumn{3}{|c|}{ Type B } & \multicolumn{3}{|c|}{ Type C } \\
\hline & & & & & & & Al & A2 & A3 & B I & B2 & B3 & $\mathrm{Cl}$ & C2 & C3 \\
\hline Plate & 28 & 30 & 15 & 13 & 17 & II & 5 & 3 & 6 & 0 & I & 2 & 3 & 3 & 7 \\
\hline DCS & 29 & 29 & 18 & 11 & 20 & 9 & 5 & 5 & 5 & 0 & 1 & 0 & 3 & 3 & 7 \\
\hline
\end{tabular}


Table 2. The results for two groups of patients treated for lower femoral fractures with condylar buttress plate and DCS

\begin{tabular}{|c|c|c|c|c|c|c|c|c|c|c|c|c|c|c|c|c|c|c|}
\hline \multirow[t]{2}{*}{ Type/no } & \multicolumn{8}{|c|}{ Plate group } & \multirow[t]{2}{*}{ Sum } & \multicolumn{8}{|c|}{ DCS group } & \multirow[t]{2}{*}{ Sum } \\
\hline & Al & A2 & A3 & B2 & B3 & Cl & C2 & C3 & & Al & A2 & A3 & B2 & B3 & Cl & C2 & C3 & \\
\hline & 5 & 3 & 6 & 1 & 2 & 3 & 3 & 7 & 30 & 5 & 5 & 5 & 1 & 0 & 3 & 3 & 7 & 29 \\
\hline \multicolumn{19}{|l|}{ Reduction } \\
\hline Adequate & 5 & 3 & 2 & I & $\mathrm{I}$ & 2 & 3 & 3 & 20 (67\%) & 3 & 3 & 5 & 1 & 0 & 2 & 2 & 5 & 21 (72.4\%) \\
\hline Inadequate & 0 & 0 & 4 & 0 & I & 1 & 0 & 4 & 10 (33\%) & 2 & 2 & 0 & 0 & 0 & I & 1 & 2 & $8(27.6 \%)$ \\
\hline Shortening & 0 & 0 & 3 & 0 & 0 & 0 & 0 & 4 & 7 (25\%) & I & 2 & 0 & 0 & 0 & I & I & 2 & 7 (24\%) \\
\hline Flexion deficit & 1 & 1 & 3 & I & 2 & 1 & 0 & 5 & 14 (50\%) & 1 & 2 & 3 & 1 & 0 & 1 & 1 & 4 & $13(45 \%)$ \\
\hline Pain & 0 & 0 & 0 & 0 & 0 & 0 & 0 & 2 & 2 & 0 & 0 & I & 0 & 0 & 0 & 0 & 0 & 1 \\
\hline \multicolumn{19}{|l|}{ Complications } \\
\hline Tf & 0 & 0 & 0 & 0 & $\mathrm{I}$ & 0 & 0 & 2 & 3 & 0 & I & 0 & 0 & 0 & $\mathrm{I}$ & 0 & 2 & 4 \\
\hline Infection & 0 & 0 & 0 & 0 & 0 & 0 & 0 & 2 & 2 & 0 & I & 1 & 0 & 0 & 0 & 0 & 0 & 2 \\
\hline Nonunion & 0 & 0 & 0 & 0 & 0 & 0 & 0 & 0 & 0 & 0 & 0 & 1 & 0 & 0 & 0 & 0 & 0 & 1 \\
\hline \multicolumn{19}{|l|}{ Grading } \\
\hline Excellent & 4 & 2 & 3 & 0 & - & 2 & 3 & 2 & 16 (57\%) & 4 & 3 & 2 & 0 & 0 & 1 & 2 & 4 & 16 (55\%) \\
\hline Good & I & 1 & 1 & 1 & - & 0 & 0 & 1 & $5(18 \%)$ & 1 & I & 2 & 1 & 0 & 2 & 1 & 2 & $10(34.5 \%)$ \\
\hline Fair & 0 & 0 & 2 & 0 & - & 1 & 0 & 2 & $5(18 \%)$ & 0 & I & 0 & 0 & 0 & 0 & I & 0 & $2(7 \%)$ \\
\hline Poor & 0 & 0 & 0 & 0 & - & 0 & 0 & 2 & $2(7 \%)$ & 0 & 0 & I & 0 & 0 & 0 & 0 & 0 & I (3.5\%) \\
\hline
\end{tabular}

Tf: Technical failure.

mal and distal segments in 8 fractures $(26.7 \%)$ and rotation in one fracture $(3.3 \%)$. Reasons for inadequacy of reduction in the DCS group were posterior angulation in 5 fractures (17\%), displacement between main proximal and distal segments in 7 fractures (24\%) and rotation in 2 fractures $(6.9 \%)$. In both groups, there was more than one reason for inadequacy of reduction per one fracture. It was remarkable that the posterior angulation was detected in the DCS group (Fig. I); however, it was not observed in the plate group.

The fractures united within an average period of 15.5 weeks (8-28 weeks) in the plate group and 12.8 weeks (8-24 weeks) in the DCS group. Non-union was reported in one patient in the DCS group.
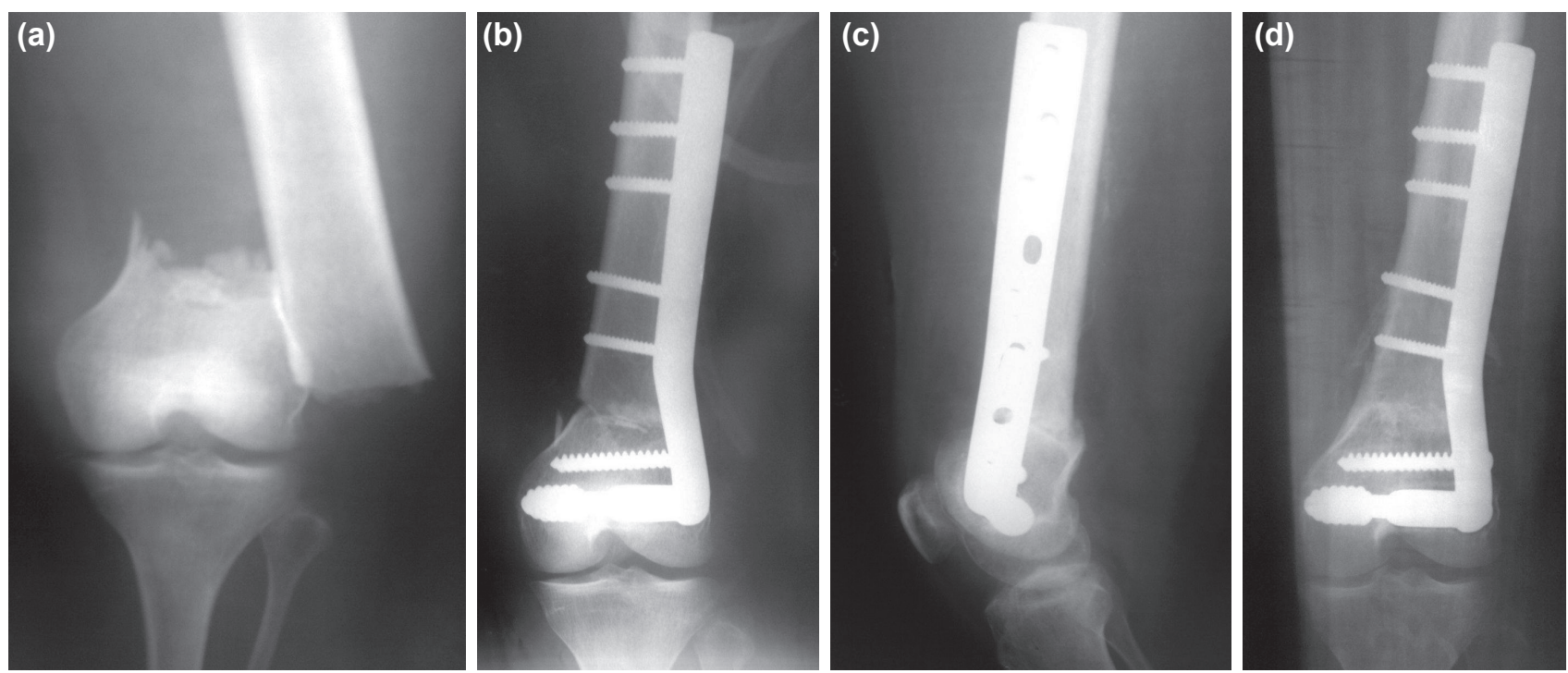

Figure 1. (a) Preoperative anteroposterior (AP) radiograph for right knee of a 45-year-old female shows AO type A1 lower femoral fracture; (b, c) the AP and lateral radiographs made immediately postoperative shows the fracture was fixed with DCS. The AP view shows medial cortical defect and the lateral view shows posterior angulation; (d) shows healed fracture with no varus collapse. 
Full knee motion range compared to contralateral side was achieved in fourteen patients (50\%) of plate group and in sixteen patients (55\%) in the DCS group (Table 2). The difference between the two groups using $Z$ test, was statistically insignificant $(p=0.69654)$. Extension lag was not reported in any of the groups even in those with posterior angulation. Flexion deficit in the plate group averaged $10.5^{\circ}(\mathrm{SD}=11.7$, range $\left.0-30^{\circ}\right)$ and in the DCS group averaged $10.3^{\circ}(S D=12.7$, range $0-40^{\circ}$ ). The difference between the two groups using $U$ test, was statistically insignificant $(p=0.90448)$.

Leg length inequality was reported in seven patients (25\%) in the plate group and in seven patients $(24 \%)$ in the DCS group (Table 2). The difference between the two groups using $Z$ test was statistically insignificant $(p=0.93624)$. Leg shortening in the plate group averaged $0.5 \mathrm{~cm}(S D=0.88$, range $0-2 \mathrm{~cm})$ and in the DCS group averaged $0.3 \mathrm{~cm}(S D=0.5 \mathrm{I}$, range $0-1.5$ $\mathrm{cm})$. The difference between the two groups using $U$ test was statistically insignificant $(p=0.67448)$. Persistent pain was reported in two patients of the plate group and in one patient of the DCS group (Table 2).

Functional outcomes (Table 2) in the plate group were reported as satisfactory (excellent and good) in twenty-one patients (75\%) and unsatisfactory (fair and poor) in seven (25\%). In the DCS group, satisfactory results were reported in twenty-six patients $(90 \%)$ and unsatisfactory in three (10\%). The difference between the two groups using $Z$ test was statistically insignificant $(p=0.14706)$.

\section{Complications}

Technical failure and deep infections were reported in five patients (17.9\%) of the plate group and in six patients $(20.7 \%)$ of the DCS group (Table 2). The difference between the two groups using $Z$ test was statistically insignificant $(p=0.645 \mid 4)$. Technical failure due to displacement between fragments of the articular block was reported in 3 fractures (10\%) of the plate group and in 3 fractures (10.3\%) of the DCS group. Screw penetration of the distal articular block exclusively reported in one patient of the DCS group. The lag screw was reinserted soundly once discovered.

Deep infection was reported in two fractures in each group, three fractures healed after surgical intervention and parenteral antibiotics. The fourth was in the DCS group, an obese diabetic female with type $A 3$ fracture. Deep infection was not controlled and the fracture was not united at the end of the follow-up period despite extensive surgical debridement, parenteral antibiotics and two attempts for bone grafting. Superficial wound infection was reported in three and five patients of the plate and DCS groups, respectively. In one patient of the DCS group with type AI fracture, lag screw penetration of the medial cortex was observed. Upon bone healing, the lag screw was removed through small medial and lateral incisions, and rest of the DCS components were left (Fig. 2).

\section{DISCUSSION}

Condylar buttress plate has comparable advantages as DCS
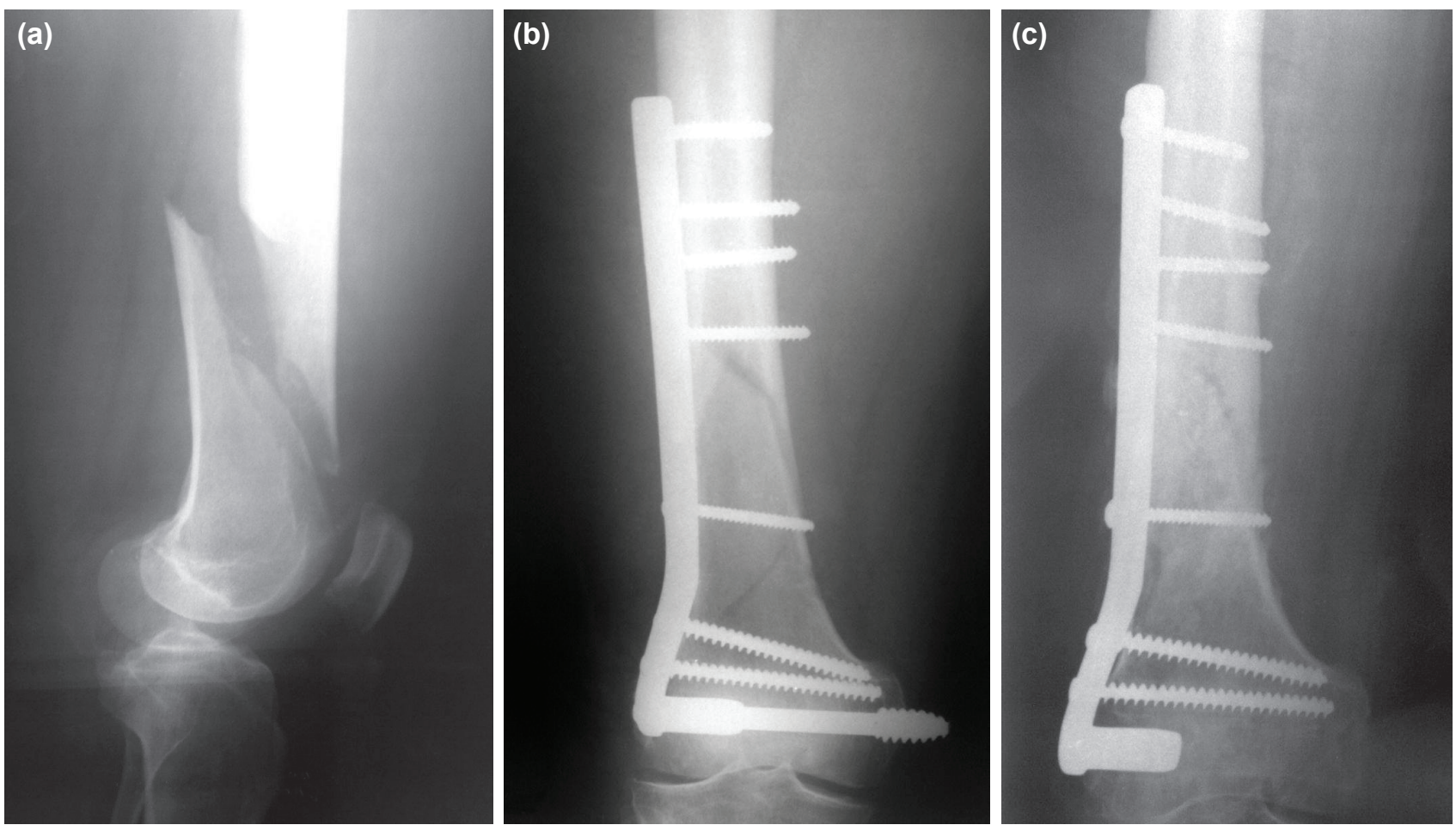

Figure 2. (a) Preoperative AP radiograph for left knee of a 57-year-old male shows AO type A1 lower femoral fracture; (b) AP radiograph made one month postoperatively shows lag screw penetration of the medial cortex; (c) AP radiograph made 6 months postoperatively shows healed fracture and lag screw was removed, rest of DCS composite was left. 
such as familiarity and liberty for surgeons to reduce anatomically the distal fragment(s). However, it is required to know whether full knee motion range will be restored by using any of them.

Angle blade plates have been reported to give good results, ${ }^{[9]}$ but the need to hammer the implant into position risks separating the femoral condyles. ${ }^{[10]} \mathrm{DCS}$, which has a design analogous to that of the angled plate, is technically easier to apply and allows more freedom in the coronal and sagittal planes since the plate and screw are separate pieces. ${ }^{\left[{ }^{I I}\right]}$ Thereby, it makes accurate reduction, particularly when the fractures are intra-articular and the lag screw held well, even in osteoporotic bone. ${ }^{[10]}$ Moreover, DCS did not fail with fatigue testing. ${ }^{[12]}$ On the other hand, the condylar buttress plate was designed to allow multiple lag screw fixations of complex condylar fractures. However, this plate is not a fixed-angle device, and therefore, does not maintain correct alignment of the joint axis. ${ }^{[13]}$

Alignment of the distal articular block of the femur is the main treatment concern. Although the DCS design has the described stability, posterior angulation was reported in five fractures in the DCS group. In the earlier cases of the study, we had used one plate holding forceps prior to insertion of the cortical screws to the proximal bone segment, as we usually do with proximal femoral fractures, which allowed rotation of the distal segment around the lag screw, and consequently, posterior angulation (Fig. I). Once the error was realised, the second inserted screw was inserted to distal segment. When the distal segment was excessively short, a plate holding forceps was used to resist the rotation. In this way, posterior angulation was not observed again.

Posterior angulation was not reported in the plate group, which in our standpoint, was attributed to the fact that the plate was initially held with plate holder forceps, and distal end of the plate allowed multiple lag screw insertion. However, the plate group reported varus angulation in four fractures. The collapse of the distal fragment into varus has previously been attributed to the fact that individual lag screws are not fixed to the plate, and therefore it can easily shift their angulation relative to it. ${ }^{[13]}$ A biomechanical study related varus angulation to decreased rigidity and strength of this device. ${ }^{[14]}$ For maintenance of fixation, some authors have adopted double plating, placement of angulated screw in the lateral condylar buttress plate (Fig. 3) or locked plating. ${ }^{[13-15]}$

Flexion deficit has serious effects on the daily activities of Eastern peoples. Moreover, it may accelerate hip joint damage or loosening of hip endoprostheses. ${ }^{[16]}$ The relevant authors have concluded the etiology of flexion loss in intra and extra articular possibilities such as mal reduction of the articular surface, arthrofibrosis, hardware penetration, capsular contractures or muscular scarring. ${ }^{[17,18]}$ In the current study, flexion deficit was reported with intra articular fractures as well as with intact articular block, which theoretically, meant that the cause of deficit probably related to extra articular
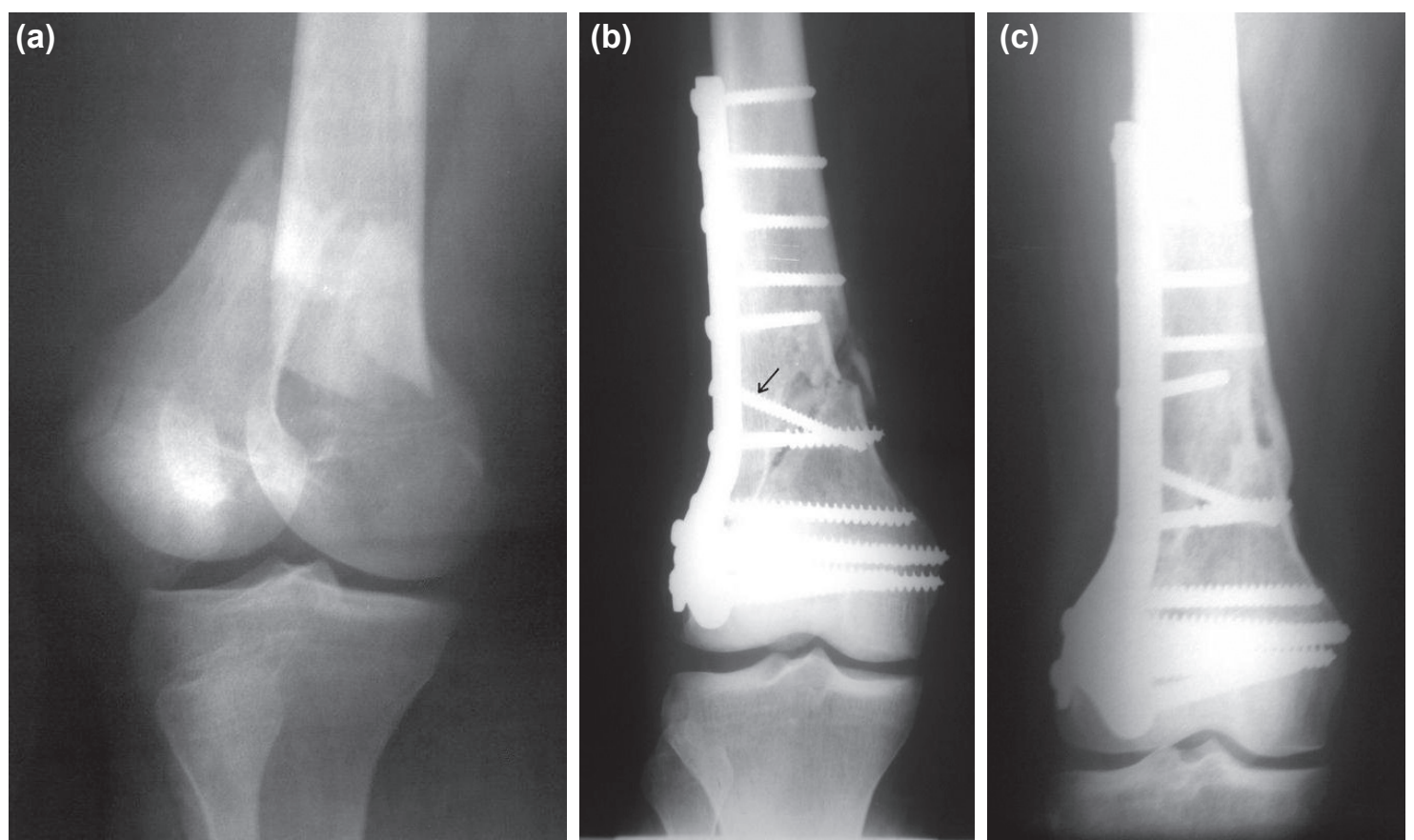

Figure 3. (a) Preoperative AP radiograph for left knee of a 30-year-old male shows AO type C2 lower femoral fracture; (b) $\mathrm{AP}$ radiograph made one month postoperatively shows the fracture was fixed with condylar buttress plate, and there is a medial cortical defect. A screw was placed diagonally across the fracture site (arrow) (c) AP radiograph made 6 months postoperatively shows healed fracture with no varus angulation. Screw angulation in the plate strengthened the overall construct to resist the tendency toward varus deformity. ${ }^{[14]}$ 
causes. Anterior adhesions was observed by authors practicing arthroscopic release in post-traumatic stiff knees. Anterior adhesions involve quadriceps expansion in the lateral and medial recesses, the suprapatellar bursa, muscle adhesions to the femur, or even shortening of the rectus femoris. ${ }^{[17]}$ Excursion of the quadriceps, when the knee is flexed from zero to 90 degrees, has been shown to be six to eight centimetres. Therefore, any condition that injures the quadriceps, like a supracondylar femoral fracture, will result in limitation of the muscle elongation with loss of knee flexion. ${ }^{\left[{ }^{19]}\right.}$ Extension lag, even with posterior angulation, was not reported in the study. Brown et al. have reported that a lag in extension was present in every patient for some weeks following the operation; however, in no case did it persist. ${ }^{[20]}$

Flexion deficit was observed when the lag screw of the DCS was misplaced. In a case with type AI supracondylar fracture, after assembly of the DCS components, passive flexion deficit was noticed. Mal-positioning of the distal femoral articular block was suspected. Mal-positioning affects patellofemoral kinematics, and abnormal tensioning of the soft tissues may also occur. ${ }^{[21,22]}$ Using a triple reamer, the lag screw hole is re-reamed to a distance shorter than the screw length, which allows the distal articular block to move around the plate nozzle and relaxes the soft tissues. Thus, again tested passive flexion range increased.

\section{Conclusion}

No implant is superior to the other for restoration of knee motion when used for treatment of distal femoral fracture. Applications of the condylar buttress plate and DCS are liable for technical optimization.

\section{Acknowledgement}

I am most grateful to pharmacist Abdulsamad Mahran-Sohag Teaching Hospital-for making of the statistics of the present study.

Conflict of interest: None declared.

\section{REFERENCES}

1. Neer CS 2nd, Grantham SA, Shelton ML. Supracondylar fracture of the adult femur. A study of one hundred and ten cases. J Bone Joint Surg Am 1967;49:591-613.

2. El-Kawy S, Ansara S, Moftah A, Shalaby H, Varughese V. Retrograde femoral nailing in elderly patients with supracondylar fracture femur; is it the answer for a clinical problem? Int Orthop 2007;31:83-6. CrossRef

3. Saw A, Lau CP. Supracondylar nailing for difficult distal femur fractures. J Orthop Surg (Hong Kong) 2003;11:141-7.
4. Wähnert D, Hoffmeier KL, von Oldenburg G, Fröber R, Hofmann GO, Mückley T. Internal fixation of type-C distal femoral fractures in osteoporotic bone. J Bone Joint Surg Am 2010;92:1442-52. CrossRef

5. Charles A. In Rockwood and Green's fractures in adults, 7th ed., vol. 1, Lippincott, Philadelphia 2010. p. 666-73.

6. Keats TE, Teeslink R, Diamond AE, Williams JH. Normal axial relationships of the major joints. Radiology 1966;87:904-7. CrossRef

7. Krettek C, Miclau T, Grün O, Schandelmaier P, Tscherne H. Intraoperative control of axes, rotation and length in femoral and tibial fractures. Technical note. Injury 1998;29 Suppl 3:29-39. CrossRef

8. Schatzker J, Lambert DC. Supracondylar fractures of the femur. Clin Orthop Relat Res 1979;138:77-83.

9. Yang RS, Liu HC, Liu TK. Supracondylar fractures of the femur. J Trauma. 1990;30:315-9. CrossRef

10. Shewring DJ, Meggitt BF. Fractures of the distal femur treated with the AO dynamic condylar screw. J Bone Joint Surg Br 1992;74:122-5.

11. Petsatodis G, Chatzisymeon A, Antonarakos P, Givissis P, Papadopoulos P, Christodoulou A. Condylar buttress plate versus fixed angle condylar blade plate versus dynamic condylar screw for supracondylar intra-articular distal femoral fractures. J Orthop Surg (Hong Kong) 2010;18:35-8.

12. Heiney JP, Barnett MD, Vrabec GA, Schoenfeld AJ, Baji A, Njus GO. Distal femoral fixation: a biomechanical comparison of trigen retrograde intramedullary (i.m.) nail, dynamic condylar screw (DCS), and locking compression plate (LCP) condylar plate. J Trauma 2009;66:443-9. CrossRef

13. Sanders R, Swiontkowski M, Rosen H, Helfet D. Double-plating of comminuted, unstable fractures of the distal part of the femur. J Bone Joint Surg Am 1991;73:341-6.

14. Simonian PT, Thompson GJ, Emley W, Harrington RM, Benirschke SK, Swiontkowski MF. Angulated screw placement in the lateral condylar buttress plate for supracondylar femoral fractures. Injury 1998;29:101-4.

15. Hoffmann MF, Jones CB, Sietsema DL, Tornetta P 3rd, Koenig SJ. Clinical outcomes of locked plating of distal femoral fractures in a retrospective cohort. J Orthop Surg Res 2013;8:43. CrossRef

16. Fleckenstein SJ, Kirby RL, MacLeod DA. Effect of limited knee-flexion range on peak hip moments of force while transferring from sitting to standing. J Biomech 1988;21:915-8. CrossRef

17. Dhillon MS, Panday AK, Aggarwal S, Nagi ON. Extra articular arthroscopic release in post-traumatic stiff knees: a prospective study of endoscopic quadriceps and patellar release. Acta Orthop Belg 2005;71:197-203.

18. Link BC, Babst R. Current concepts in fractures of the distal femur. Acta Chir Orthop Traumatol Cech 2012;79:11-20.

19. Wendt PP, Johnson RP. A study of quadriceps excursion, torque, and the effect of patellectomy on cadaver knees. J Bone Joint Surg Am 1985;67:726-32.

20. Brown A, D'Arcy JC. Internal fixation for supracondylar fractures of the femur in the elderly patient. J Bone Joint Surg Br 1971;53:420-4.

21. Akagi M, Matsusue Y, Mata T, Asada Y, Horiguchi M, Iida H, et al. Effect of rotational alignment on patellar tracking in total knee arthroplasty. Clin Orthop Relat Res 1999;366:155-63. CrossRef

22. Ghosh KM, Merican AM, Iranpour F, Deehan DJ, Amis AA. The effect of femoral component rotation on the extensor retinaculum of the knee.J Orthop Res 2010;28:1136-41. CrossRef 


\section{ORİJINAL ÇALIŞMA - ÖZET}

\section{Distal femoral fraktürlerin fiksasyonu: Diz kinematiğinin restorasyonu}

\section{Dr. Elsayed Ibraheem Elsayed Massoud}

Sohag Eğitim Hastanesi, Ortopedi Kliniği, Eğitim Hastaneleri ve Enstitüleri Genel Organizasyonu, Sohag, Mısır

AMAÇ: İyileşmiş distal femur kırıkları diz hareketlerinde çeşitli derecelerde kayıplara neden olmaktadır. Günlük aktiviteler için yere çömelme ve oturma gereği duyan Doğu toplumları için ciddi bir sorundur. Bu çalışmanın amacı, distal femur kırıklarında kondil destek plağı ve dinamik kondil vidası (DKV) kullanımının sonuçlarını karşılaştırmaktı. İncelenen implantların teknik uygulamasının optimizasyonunda klinik deneyimlerimizi sunduk. GEREÇ VE YÖNTEM: İki gruba ayrılmış (plak ve DCS) 57 hastanın 59 distal femur kırıkları kondil destek plağı veya DKV ile tedavi edilmiş ve ileriye yönelik olarak 24 ay izlenmiştir.

BULGULAR: Plak grubu için kırıkların \%67'sinde yeterli redüksiyon ve \% /3.3'ünde varus angülasyonu bildirilmiştir. DKS grubunda kırıkların \%72.4'ünde yeterli redüksiyon ve \%17'sinde posteriyor angülasyon bildirilmiştir. Her iki grupta redüksiyon yetersizliğinin diğer nedenleri de rapor edilmiştir. Plak grubundakilerin \%50 ve DKS grubundakilerin \%55'inde tam olarak diz hareket erimi gerçekleşmiştir. Plak ve DKS grubunda sırasıyla $\% 75$ ve \%90 oranında tatmin edici fonksiyonel sonuçlar bildirilmiştir.

TARTIŞMA: Diz kinematiğinin restorasyonu açısından her iki implant ile hemen hemen benzer sonuçlar elde edilmiştir. Kondil destek plağı ve DKS teknik açıdan optimal düzeye getirilebilir.

Anahtar sözcükler: Dinamik kondil vidası; distal femur; diz motilitesi; fraktür; kondil destek plağı.

Ulus Travma Acil Cerrahi Derg 2015;2I(3):197-203 doi: 10.5505/tjtes.2015.00490 